\title{
17
}

\section{SWEDISH CONTRIBUTION TO AN ECOLOGICALLY SUSTAINABLE SOCIETY}

Bobby Mrozowski

$B B$ Innovation \& Co $A B$

Sweden

\section{INTRODUCTION}

The conventional water supply and sewage-system needs a change at both a technical and mental level.

System ecological thinking is required in order gradually to convert to an ecologically sustainable society, as well as more humility among decision-makers.

The Earth is five billion years old. Mankind has been found on this planet for only a couple of million years, but over the last 100 years we have polluted nature and the environment at such a rate that we are approaching a global catastrophe.

\section{Every minute}

tons of artificial fertiliser and pesticides from cultivated land leach out into lakes and oceans.

21 hectares of tropical forest are destroyed.

\section{Every hour}

685 hectares of agricultural land is transformed into desert.

1800 children die due to lack of food (15 million a year).

Pesticides poison 55 people and 5 people die only in the USA.

60 new cases of cancer are established in the USA alone. 


\section{Every day}

25000 people die due lack of water.

This is happening five years after the Rio de Janeiro declaration.

We cannot lose more time, we must act now!

\section{URINE SORTING AS A NATURAL PART OF THE WATER SUPPLY AND SEWAGE-SYSTEM ADJUSTED TO THE NATURAL CYCLE.}

Like other countries, Sweden has experienced strong growth of towns and society. More and more people are leaving the countryside and moving in to the towns, where it is easier to get job, to study and where is a more convenient lifestyle. The economic system upon which we have made ourselves dependent is destroying our ecosystem.

We consume on credit.

Leave residual products behind us and create environmental problems.

Cost is increasing and the unpaid bill is growing. Who shall pay?

We have to take responsibility for future generation.

During my trips to the USA, I came into contact with the Indians.

There I had a more rigorous thought.

The Indians have always lived close to the nature and with nature and when they had to make decisions, they always thought several generations ahead.

When we talked about water, they said to me NTThe white man is very peculiar, he urinates in his drinking waterî ñ they meant our Water supply and Sewage system.

There is a great deal in this.

The urine sorting system in our Urban Water Treatment and Waste Management is natural way to an ecologically sustainable society.

\section{UNDERNOURISHED FIELDS - OVERFED SEAS}

We are doing the wrong things in the wrong places, and are creating problems.than we build very large water treatment plats and create even greater problems. The subject is NPK - NITROGEN - PHOSPHORUS and POTASSIUM. It is about plant nourishment and organic material, which must be returned to the fields from which they came. It is about the valuable human urine that today ends up via water treatment plants in our lakes and seas and contributes to overfeeding.

This involves gradually recreating the balance, changing over to ecological agriculture, and having nutritious food without the trades fertilizers and pesticides. 
It is about having healthy children without allergy problems.

It is about having an ecologically sustainable society.

It is about URINE SORTING as a natural part of the water supply and sewage ñsystem adjusted to the natural cycle.

\section{HUMAN URINEIS QUALTYY AS A FERTILIZER}

The standard values the content of NPK in domestic water (SNV 1995)

\begin{tabular}{|c|c|c|c|}
\hline & Urine $(\mathbf{g} / \mathbf{p d})$ & Faeces $(\mathbf{g} / \mathbf{p d})$ & Grey water $(\mathbf{g} / \mathbf{p d})$ \\
\hline Nitrogen & $80 \%(11)$ & $10 \%(1,5)$ & $10 \%(1,0)$ \\
\hline Phosphorus & $50 \%(1,0)$ & $25 \%(0,5)$ & $25 \%(0,6)$ \\
\hline Potassium & $60 \%(2,5)$ & $25 \%(1,0)$ & $15 \%(0,5)$ \\
\hline
\end{tabular}

Nitrogen remains in human urine to over $90 \%$ as ammonium. Crops take up this form of nitrogen very easily. Cultivation trials have shown that crops also very easily take up the phosphorus, which is found in human urine.

As well as NPK, human urine contains a wide range of micronutrient substances and trace elements, which are valuable in plant cultivation.

Through sorting and returning the urine to agriculture, a high degree of recycling of the growth substances is achieved.

\section{A NEW GENERATION OF EXTREMELY LOW FLUSH AND URINE SORTING WATER CLOSETS ARE BORN}

Nowadays man (despite environmental commitment) become comfortable and is used to a certain standard, especially in the industrialized countries.

We must remember this.

We cannot and shall not turn the clock back, we must move forwards with new, environmentally adjusted technology, which corresponds, to the requirements we have today on a hygienic, aesthetic and technical level.

During the spring of 1991 , we started to work on a concept of completely new generation water closets adjusted to the natural cycle.

It is based on the inventor Bibbi Söderberg's idea and design.

We chose our own way and ended up in the beginning in N no manses land $\tilde{\mathrm{N}}$ between fundamentalists who tried to convince themselves that Dry-toilet can function in permanently occupied housing in urban environment, and the conservative establishment which has been affected by a temporary lack of oxygen and has given up intellectual thought activity.

At the Ecological Architecture Conference in Stockholm, August 18-20 1992, arranged by (KTH ) The Royal Institute of Technology, the prototype for a new ecological water closet, DUBBLETTEN was shown to the public for the first time. 
In June 1993, DUBBLETTEN was shown at the Chicago Architects Convention, invited by J.R.Berkebile, chairman of the AA Committee of the Environment in the USA. In July 1993, a Swedish Patent was granted.

In July 1993, an invitation was given to the Permakultur Conference in Copenhagen.

In May 1994, it was displayed at Teknikens Torg in Östersund during the "Kvinnor Kan" (Women-Can) trade fair at the invitation of Swedish Patent and RegistrationOffice and the Swedish Inventors Association.

Leading Swedish politicians have shown great interest.

This new generation of toilets has revolutionized water supply and sewage system management in Sweden. It has created a debate and shown the way for constructive work on changing over to an ecologically sustainable society with maintained high standards.

The user obtains elegant porcelain sanitary ware suspended on the wall, with a water lock and water flushing, and no odor problems.

Thanks to its unique design, we can sawe approximately $80 \%$ of flushing water in comparison with a normal toilet.

\section{THE TECHNICAL REQUIREMENTS WHICH MUST BE IMPOSED FOR A URINE SORTING WATER CLOSET}

"Risks with recycling of human waste".

Anna Olsson and Thor Axel Stenstr^m, Institute of Infectious Diseases.

"The occurrence of micro-organisms is primarily concentrated in the faeces while urine as a rule does not contain illness-promoting organisms.

The urine sorting system aims to sort the faeces from urine, but when the design of the urine sorting toilet is not optimal, there is risk that faecal microorganisms will mix with the urine".

DUBBLETTEN'S unique patented design is based on two, well separated bowls, the one behind, for faeces, has a bulge which prevents an overflow of the flushing water infected with bacteria and viruses to the front, well separated, urine bowl.

Through the two well separated bowls and two flushing systems which are independent of each other, a minimum of water end the urine tank ( Håkan Jönsson SLU of Uppsala University. results of measurement at Understenshöjden in Stockholm, of one liter urine only $3 \mathrm{dl}$ was flushing water.)

Behind DUBBLETTEN'S unique design lie several years of development work. Special moulds were built.

A number of tests have been carried out in the laboratory in order to produce a suitable casting compound, which would cope with the shape in the firing. 
All this in order to fulfil the requirements which shall give safe and sanitary sorting of urine from bacteria-carrying faeces and in order to be able to retum human urine to agricultural land and the natural cycle.

\section{STORAGE SYSTEM FOR URINE}

In order to create the best preconditions for the management of human urine that shall be retumed to agriculture and the natural cycle, specially designed toilet is also required as well as an adjusted storage system.

$\mathrm{W}-\mathrm{C}-\mathrm{O}-\mathrm{T}$.

Water - Contamination - Oxygen - Temperature has negative influence on the urine.

The specially developed technology prevents and eliminates these factors.

The urinetank is manufactured from concrete with a patented design consisting of a float with a rubber seal in order to protect from exposure to the air, tanks are buried, standing in the ground in order to guarantee the correct storage temperature.

\section{FAECES COMPOSTING SEPARATOR}

Manufactured from concrete and equipped with two perforated rust-resistant containers with swiveling spheres at the bottom in order to bind phosphor, composting faeces and domestic organic waste.

Pipe connections are adjusted for optimal pipe types.the intanke pipe can be turned so that one container at a time can be filled altemately. The compost matures in the other one The waste water is filtered through the perforation to an underlying 2.chamber well, which is dimensioned according to Swedish Standard SS 825620 and is covered by Certification agreement ISO 9002.

Under the container, the pipes for grey water are connected to the same 2chamber tank. Leachate from the compost and grey water after a sludge separator is led to an infiltration system, for example, sub-surface filter in-drain or root zone.

\section{THE DUBBLETT SYSTEM IS INTENDED FOR ALL TYPES OF BUILDINGS}

And since the start of serial manufactures, it has been installed in schools, offices, and blocks of flats, small houses and in the leisure areas.

As well as Sweden, Dubbletten has been installed in Australia, Spain, Italy, Finland and Denmark. 


\section{REFERENCELIST OF PROJECTS WHERE DUBBLETTEN HAS BEEN INSTALLED.}

Palsternacka - hyreshusområde - Stockholmhem AB.

Understenshöjden - radhusområde - HSB Stockholm.

Grafikens Hus -Gripsholms slott kungsladugård - Mariefred.

Ekohusets vänner - Nynäshamns Kommun.

Hebrant Bygg \& Kretslopp - Huddinge Kommun.

Naturliga Steget - Slotsbacken - Stockholm.

Naturskola - Överjärva Gård - Solna Kommun.

Åkeshov Reningsverk - Stockholm Vatten AB .

Sandåkerskolan -Landskrona Kommun.

Hyltebrukskolan - Hylte Kommun.

Laggarbersskola - Timrå Kommun.

Vallenskola -Sundsvall Kommun.

Strömsboskola - Gävle Kommun.

Klövsjö IF - Klubblokaler

TeknikensHus - Luleå Kommun.

Norrköpings Hyresbostäder Kv. Porten.

Bostads bolag Poseidon - Göteborg.

Hallsbergs Byggnadsstiftelse (HSB) - Höghus.

Jönköping Kommun - Pia Larsson.

Borlänge Kommun - Miljöchef Kjell Olsson.

Vallentuna Kommun - Bibliotek.

Enångers Båtsällskap -Enånger.

Hushållningssällskapets - Lilla Böslid - Halmstad.

Hyltebrukskolan i Hylte kommun.

Lantbruksgård - Nöttja i Småland.

Mejeriet Mariehov - Söderköpings Kommun.

Nygård - Berttil Gustavsson i Alle Kommun.

Stiftelsen Saltå i Jäma - Arbetsskola.

Gotlands Kommun - Miljö \& Hälsa Kontor.

Muramari Herrgård och Säveskolan i Visby på Gotland.

Valsängs Ekoby - Klävedal på Orust.

Skällens Kretsloppscentrum i Torsås Kommun.

Vaxholm Kommun - Ytterbystrand - P.ALindhal.

Rosengårds Herrgård - Malmö.

Gnosjö Kunskapcentrum,Landshövdingehus på Lindholmen i Göteborg,

Frillesåsskolan in Kungsbacka, Teknikhuset in Kalmar Universitet, Hoting Sjukhem in Östersund, Långskataskolan in Piteå, Starrkärrs skola in Kungsbacka, Brunn skola Värmdö, Östra Torn skola in Lund, Kv. Inspektoren Kalmarhem AB in Kalmar, Vitlycke Museum in Tanum. 